\title{
Iodine and bromine speciation in snow and the effect of orographically induced precipitation
}

\author{
B. S. Gilfedder ${ }^{1}$, M. Petri ${ }^{2}$, and H. Biester ${ }^{1}$ \\ ${ }^{1}$ Institut für Umweltgeochemie, Neuenheimer Feld 236, 69120 Heidelberg, Germany \\ ${ }^{2}$ Bodensee-Wasserversorgung, Sipplingen Laboratory, Germany
}

Received: 17 November 2006 - Published in Atmos. Chem. Phys. Discuss.: 22 January 2007

Revised: 2 May 2007 - Accepted: 3 May 2007 - Published: 21 May 2007

\begin{abstract}
Iodine is an essential trace element for all mammals and may also influence climate through new aerosol formation. Atmospheric bromine cycling is also important due to its well-known ozone depletion capabilities. Despite precipitation being the ultimate source of iodine in the terrestrial environment, the processes effecting its distribution, speciation and transport are relatively unknown. The aim of this study was to determine the effect of orographically induced precipitation on iodine concentrations in snow and also to quantify the inorganic and organic iodine and bromine species. Snow samples were collected over an altitude profile $(\sim 840 \mathrm{~m})$ from the northern Black Forest and were analysed by ion-chromatography - inductively coupled plasma mass spectrometry (IC-ICP-MS) for iodine and bromine species and trace metals (ICP-MS). All elements and species concentrations in snow showed significant $\left(r^{2}>0.65\right)$ exponential decrease relationships with altitude despite the short $(5 \mathrm{~km})$ horizontal distance of the transect. In fact, total iodine more than halved ( 38 to $13 \mathrm{nmol} / \mathrm{l}$ ) over the $840 \mathrm{~m}$ height change. The results suggest that orographic lifting and subsequent precipitation has a major influence on iodine concentrations in snow. This orographically induced removal effect may be more important than lateral distance from the ocean in determining iodine concentrations in terrestrial precipitation. The microphysical removal process was common to all elements indicating that the iodine and bromine are internally mixed within the snow crystals. We also show that organically bound iodine is the dominant iodine species in snow (61-75\%), followed by iodide. Iodate was only found in two samples despite a detection limit of $0.3 \mathrm{nmol} / \mathrm{l}$. Two unknown but most likely anionic organo-I species were also identified in IC-ICP-MS chromatograms and comprised 2$10 \%$ of the total iodine. The majority of the bromine was inorganic bromide with a max. of $32 \%$ organo-Br.
\end{abstract}

Correspondence to: B. S. Gilfedder

(benjamin.gilfedder@ugc.uni-heidelberg.de)

\section{Introduction}

Iodine is an essential nutritional element for all mammals, including humans. A lack of dietary iodine intake can lead to iodine deficiency disorders such as goiter and in more severe cases, cretinism, which can cause both mental and physical disabilities (Dobson, 1998; WHO, 2004; Slavin, 2005). Iodine transport from the oceans by clouds and aerosols and subsequent precipitation as rain or snow is one of the primary factors influencing iodine levels and availability on the continents (Whitehead, 1984; Fuge and Johnson, 1986; Krupp and Aumann, 1999; Moran et al., 2002). However, there is also conflicting evidence regarding the terrestrial processes effecting iodine concentrations in rainfall and particularly with the suggestion that iodine levels decrease with distance from the ocean (Fuge and Johnson, 1986; Krupp and Aumann, 1999; Schnell and Aumann, 1999; Slavin, 2005). Most studies concentrate on lateral distances and to the best of our knowledge there has been only one other study focusing on the influence of orographically induced precipitation on iodine levels in rainfall (Duce et al., 1965). Iodine in rainfall is not a simple product of sea spray as observed for $\mathrm{Cl}$, with large (100-10000) enrichment factors in both rain and aerosols compared to ocean water (Duce et al., 1965; Duce et al., 1967; Winchester and Duce, 1967; Woodcock et al., 1971; Sturges and Barrie, 1988). Bubble bursting and ejection of iodine rich material from the ocean surface microlayer is one possible mechanism for the iodine enrichments (Seto and Duce, 1972), although this can only produce, at maximum, an enrichment factor of $\sim 50$. Therefore, condensation of gaseous biogenic iodine compounds onto (or forming) aerosols is required to explain the large iodine enrichments observed in aerosols and rainfall (Woodcock et al., 1971; Moyers and Duce, 1972; Duce and Hoffman, 1976; O'Dowd et al., 2002; Baker, 2005). Although research on iodine in rainfall is still limited, iodine levels and particularly speciation in snow is almost non-existent.

Published by Copernicus Publications on behalf of the European Geosciences Union. 
Snow is an important factor in the hydrological cycle during winter at higher latitudes and as such warrants further attention. One explanation for the lack of speciation data is undoubtedly the very low concentrations of individual iodine species in rain and snow and therefore methods for reliable speciation are often complex or unavailable. However, with the wide spread use of ICP-MS and the ability to couple an ion chromatograph to this extraordinarily sensitive instrument (Heumann et al., 1998; Gilfedder et al., 2007) it is possible to measure anionic iodine and bromine species down to sub nmol concentrations. One of the features of this method is that many interfering ions, such as $\mathrm{Cl}$, are separated from the element of interest and therefore the sensitivity of individual species is even greater than observed for total concentrations. Iodine speciation is also of interest for atmospheric iodine cycling as there is a discrepancy between most model calculations, which suggest that iodate should be the dominant iodine species in the particulate phase (Vogt et al., 1999; McFiggans et al., 2000), and field observations which show that organically bound iodine and iodide are the dominant iodine species (Baker et al., 2001; Baker, 2004, 2005; Gilfedder et al., 2007). Recent modeling work to reconcile this discrepancy further highlights the potential importance of organo-I in atmospheric chemistry cycles (Pechtl et al., 2007). For example, organo-I has implications for the sea/atmosphere fractionation mechanism that concentrates iodine in aerosols and rain and perhaps for iodine's effectiveness in destroying tropospheric ozone (Duce and Hoffman, 1976; Calvert and Lindberg, 2004; Baker, 2005). Bromine is also of interest in atmospheric research due to (1) its well-known ozone depletion capabilities, and (2) the interesting observation that activated bromine $\left(\mathrm{Br}_{2}\right)$ is librated from larger size aerosols causing bromine depletion relative to seawater, whereas small aerosols tend to be enriched in bromine (Sander et al., 2003). In this work we investigate the changes in iodine and bromine species (including the organically bound fraction), and metal concentrations in snow with altitude. The primary aims of this study are to clarify the role of microphysical landscape features (mountains) and the associated atmospheric processes (orographically induced precipitation) on the distribution of iodine and bromine as well as determine the dominant iodine species in snow.

\section{Methods}

A transect for snow sampling was selected in the northern Black Forest between the village of Ottenhöfen (326 m a.s.l.) and the summit of the highest peak in the area; "Hornisgrinde" (1164 $\mathrm{m}$ a.s.l.). This transect was chosen to minimize the horizontal distance $(5 \mathrm{~km})$ and maximize changes in elevation. Fresh snow was collected on 11 and 12 February 2006 in new LDPE bottles at selected locations between Ottenhöfen and Hornisgrinde along the hiking track "Elsa Weg”. Back trajectories (HYSPLIT model; http://www.arl. noaa.gov/ready/hysplit4.html) of air masses arriving at the site were calculated for the previous six days with a new trajectory starting each day at 0h UTC using an altitude of $500 \mathrm{~m}$ above ground level and the FNL meteorological database (Fig. 1). The data show that the majority of the precipitation sampled was derived from the Atlantic Ocean. Also, the weather system had passed from the low lands to the west of the sampling site before being orographically lifted over the Black Forest mountain range. All samples were collected from open areas and clearings in the forest. Four samples were also taken on 26 January 2006 at a height of $1034 \mathrm{~m}$ a.s.l. (Mummelsee) and again four additional samples were taken in mid April (14/04/06) from very old snow deposits at 796 masl and above on the same transect. This remnant snow was only present due to the elevation and all snow from lower altitudes had previously melted. It appeared to be recrystallised into small ice particles and had probably undergone partial melting and refreezing. It also contained small debris from the surrounding forest on the surface which was discarded by filtering.

The snow was thawed, filtered $(0.45 \mu \mathrm{m})$ and stored at $4^{\circ} \mathrm{C}$ until analysed (max. 1 month). It has been shown that no significant changes in iodine speciation occur in samples stored for up to two months (Campos, 1997). Samples were allowed to warm to room temperature and were then analysed for total iodine and bromine by an inductively coupled plasmamass spectrometer (ICP-MS). For iodine we scanned on the only stable isotope, ${ }^{127} \mathrm{I}$, and for bromine on the ${ }^{79} \mathrm{Br}$ isotope. ${ }^{187}$ Re was added to the samples as an internal standard. Iodine and bromine species (iodide, iodate, bromide, bromate and organically bound $\mathrm{I} / \mathrm{Br}$ ) were analysed by coupling an ion chromatograph to the ICP-MS (IC-ICP-MS). Organically bound iodine and bromine was calculated as total iodine minus the sum of the inorganic species (i.e. Org-I=total $\left.\mathrm{I}-\left(\mathrm{I}^{-}+\mathrm{IO}_{3}^{-}\right)\right)$. Iodine and bromine species were quantified using a Dionex AS16 column with an AG16 guard column, $35 \mathrm{mmol} \mathrm{NaOH}$ eluent, a flow rate of $0.9 \mathrm{ml} / \mathrm{min}$ and a Meinhard nebulizer with a cyclone spray chamber on a Perkin Elmer quadrupole ICP-MS. Samples were injected into the chromatographic system with a Perkin Elmer series 200 autosampler. This method has a detection limit for aqueous iodine species of about $0.3 \mathrm{nmol} / \mathrm{l}$ and each sample has a runtime of only $12 \mathrm{~min}$. Moreover, no sample pretreatment is required. Unidentified organic iodine species were observed in all chromatograms; while not strictly correct these species have been quantified based on the iodide calibration curve. This should not pose a large problem as all iodine atoms are converted to $\mathrm{I}^{+}$in the plasma prior to quantification with the mass spectrometer. Precision was checked for total iodine and bromine by running replicates of samples from 326, 400, $560,597,614 \mathrm{~m}$ a.s.l. and triplicate analysis of the sample from $478 \mathrm{~m}$ a.s.l. The maximum relative standard deviation (RSD) for iodine was $1.3 \%$ which equated to a concentration standard deviation (SD) of $\pm 0.45 \mathrm{nmol} / 1$. For bromine the highest RSD was $4.8 \%$ with an associated SD of $\pm 4.9 \mathrm{nmol} / \mathrm{l}$. 


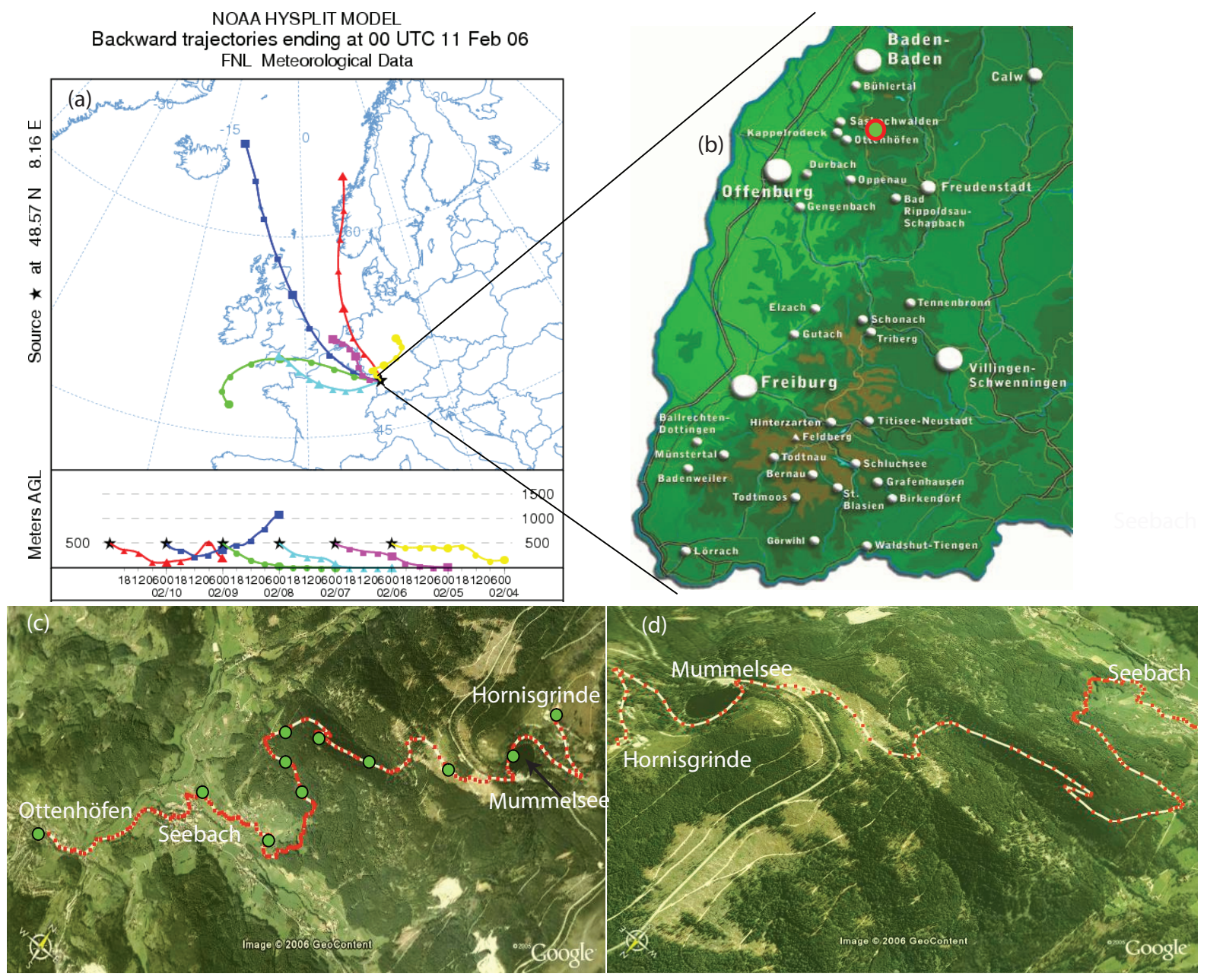

Fig. 1. (a) Europe map with sampling site and 6 day back trajectory for air parcels arriving at Ottenhöfen, (b) The Black Forest mountain range and sampling site, (c) and (d) Sampling transect and sampling sites (green circles) from Ottenhöfen (326 m a.s.1.) to Hornisgrinde (1164 m a.s.1.).

As such, a RSD of $1.3 \%$ for iodine and $4.7 \%$ for bromine was used for propagation of errors for samples where no replicates were analysed. No replicates were made for speciation, however this method (based on our experience and from other IC-ICP-MS studies (Heumann et al., 1994)) consistently has a RSD less than $2 \%$ for iodine species and between $5-7 \%$ for bromide. As such we have adopted a RSD value of $2 \%$ for iodine species and $7 \%$ for bromide when propagating errors for calculation of organo-I and organo-Br. The accuracy of total iodine, total bromine, bromide, and iodide concentrations were checked using standard reference material BCR-611. BCR-611 is a groundwater reference material with a certified bromide level of $93 \pm 4 \mu \mathrm{g} / \mathrm{l}$. It also gives indicative values for total bromine $(107 \pm 11 \mu \mathrm{g} / \mathrm{l})$, total iodine $(9.3 \pm 1.3 \mu \mathrm{g} / \mathrm{l})$, and iodide $(9.0 \pm 1.1 \mu \mathrm{g} / \mathrm{l})$. More information on this reference material can be found at the European Institute for Reference Materials and Measurements website: http://www.irmm.jrc.be. All of our values were consis- tently within the error given in the certificate except for total bromine which was slightly lower (bromide $93.5 \mu \mathrm{g} / \mathrm{l}$, total bromine $94 \mu \mathrm{g} / \mathrm{l}$, iodide $9.4 \mu \mathrm{g} / \mathrm{l}$, and total iodine $9.65 \mu \mathrm{g} / \mathrm{l}$ ). We believe that our value for total bromine is more realistic than the reference material average of $107 \mu \mathrm{g} / \mathrm{l}$, as this high concentration would imply a relatively large proportion of organically bound bromine in the groundwater, which is unlikely. After withdrawal and analysis of the halogens the remaining snowmelt was acidified to $\mathrm{pH}<2$ with suprapur ${ }^{\circledR}$ nitric acid and stored at $4^{\circ} \mathrm{C}$. The samples were analysed for total metals $(\mathrm{Li}, \mathrm{V}, \mathrm{Mn}, \mathrm{Co}, \mathrm{Rb}, \mathrm{Zn}, \mathrm{As}, \mathrm{Mo}, \mathrm{Pb}, \mathrm{Ba}$, $\mathrm{Sb}$, and U) 3 months after acidification with the ICP-MS. RSDs for metals using this method was lower than $8 \%$, usually around $2 \%$. Standard reference material TM-23.2 from Environment Canada's national water research institute was used to check the accuracy of the metal analysis after dilution by a factor of 10 to ensure that the concentrations were similar to that in the snow. This lake water reference 
Table 1. Selected correlation coefficients (r) between iodine, bromine, and metals.

\begin{tabular}{cccc}
\hline Elements & $r$ & Element & $r$ \\
\hline I-Br & 0.97 & Br-Na & 0.86 \\
I-Li & 0.92 & Br-Li & 0.96 \\
I-V & 0.98 & Br-V & 0.98 \\
I-Mn & 0.88 & Br-Mn & 0.95 \\
I-Co & 0.82 & Br-Rb & 0.90 \\
I-Pb & 0.897 & Br-As & 0.95 \\
I-Ba & 0.90 & Br-Pb & 0.96 \\
I-Sb & 0.90 & Br-Ba & 0.93 \\
I-U & 0.92 & Br-Sb & 0.96 \\
\hline
\end{tabular}

material is certified for $\mathrm{Pb}, \mathrm{Sb}, \mathrm{Mo}, \mathrm{As}, \mathrm{Ba}, \mathrm{Co}, \mathrm{Mn}, \mathrm{U}$, and $\mathrm{V}$. All analysed values were well within the error given in the certificate and deviated from the average certificate value by less than $10 \%$. More information on this reference material can be found on the Environment Canada webpage: http://www.nwri.ca/nlet/crm-e.html. Sodium was analysed by a Perkin Elmer flame AAS after the acidification. Standard deviations were calculated from five consecutive injections.

\section{Results}

Total iodine concentrations in snow samples were slightly higher than or similar to other existing studies (Duce et al., 1965; Jickells et al., 1991; Moran et al., 1999; Gilfedder et al., 2007), but decreased exponentially with increasing elevation $\left(r^{2}=0.85\right.$; Fig. 2a). Over the $838 \mathrm{~m}$ height change from Ottenhöfen (326 m a.s.l.) to Hornisgrinde (1164 m a.s.l.) total iodine levels decreased from a maximum of $38 \mathrm{nmol} / \mathrm{l}$ to $13 \mathrm{nmol} / \mathrm{l}$, respectively.

IC-ICP-MS iodine speciation analysis showed similar results to total iodine. Iodide concentrations decreased exponentially with increasing altitude from $11.4 \mathrm{nmol} / \mathrm{l}$ at Ottenhöfen to $3.9 \mathrm{nmol} / \mathrm{l}$ at Hornisgrinde $\left(r^{2}=0.92\right.$; Fig. 2a). No iodate was observed in any of these snow samples. Organically bound iodine also decreased with altitude, with maximum concentrations at Seebach (400 ma.s.l.; $28.8 \mathrm{nmol} / \mathrm{l}$ ) and then steadily decreased to $9.1 \mathrm{nmol} / 1$ at Hornisgrinde (Fig. 2a). Organically bound iodine was the most abundant iodine species in all samples (61-75\% of total iodine), with no clear change in percentages with altitude (Supplementary Fig. 1). Interestingly, two unidentified organo-I species were consistently found in IC-ICP-MS chromatograms in all snow samples between the iodide and iodate peaks (Fig. 3). It is thought that these peaks are anionic organic iodine compounds due to their consistent separation by the anion exchange column and stable behavior. The larger of the two peaks had a retention time of $6.8 \mathrm{~min}$ and the smaller peak eluted at a slightly shorter time of $5.4 \mathrm{~min}$. These peaks generally accounted for $5-10 \%$ of the total iodine concentrations and also displayed an inverse relationship with altitude (supplementary material Table 1 - http://www.atmos-chem-phys. net/7/2661/2007/acp-7-2661-2007-supplement.zip).

Total bromine concentrations showed much the same pattern as iodine, decreasing exponentially with altitude from $129 \mathrm{nmol} / \mathrm{l}$ at Seebach to $38.8 \mathrm{nmol} / 1$ at Hornisgrinde (Fig. 2b). Bromide was also inversely correlated with altitude with an $r^{2}$ value of 0.92 . Organically bound bromine was not so well correlated with altitude $\left(r^{2}=0.66\right)$, however the trend is still clear, as with all other species: exponentially decreasing concentrations with increasing altitude. Percent organically bound bromine displayed no relationship with altitude $\left(r^{2}=0.02\right.$; data not shown). In contrast to iodine, the majority of bromine in snow was inorganic bromide (68-81\%). Bromate was not observed in any of the samples, whereas organically bound bromine accounted for $18-32 \%$ of the total bromine.

Metal concentrations also decreased exponentially with altitude (Fig. 4 and supplementary material Fig. 2 - http://www.atmos-chem-phys.net/7/2661/2007/ acp-7-2661-2007-supplement.zip). In fact, many of the metals even showed a stronger inverse relationship with altitude than iodine and bromine. Also, significant positive $(p<0.001)$ correlations between all elements, including iodine and bromine, were observed (Table 1 and supplementary material Table 1 - http://www.atmos-chem-phys.net/7/ 2661/2007/acp-7-2661-2007-supplement.zip).

Total iodine concentrations in the four snow samples taken in January from the surface of a small frozen lake at $1036 \mathrm{~m}$ a.s.l. (Mummelsee) were similar (although slightly lower) to those taken in February. Organo-I accounted for $53-62 \%$ of the total iodine in these samples and again no iodate was observed. The only notable observation for bromine from these samples is that the percent organically bound bromine is nearly identical to all other samples and is therefore relatively invariant with time (ca. 30\%). The snow sampled in April contained significantly lower iodine (av. $3.9 \mathrm{nmol} / \mathrm{l}$ ) and bromine (av. $33.4 \mathrm{nmol} / \mathrm{l}$ ) concentrations than the previous sampling tours and showed no significant relationship with altitude. These anomalously low results are undoubtedly due to partial melting and refreezing and other post depositional changes. It is thought that, due its large ionic radii, iodine is excluded from the recrystallizing ice and hence is preferentially leached from the snow during partial melting. Organo-I composed approximately $50 \%$ of the total iodine with iodide being the next most abundant species. Iodate was also observed in two chromatograms, although it was only responsible for at maximum $16 \%$ of the total iodine. Interestingly, we also observed the same unidentified iodine peak (retention time $6.8 \mathrm{~min}$ ) between the iodate and iodide peaks as noted above. This suggests that this species is stable and can remain in the snow during melting-refreezing events. 

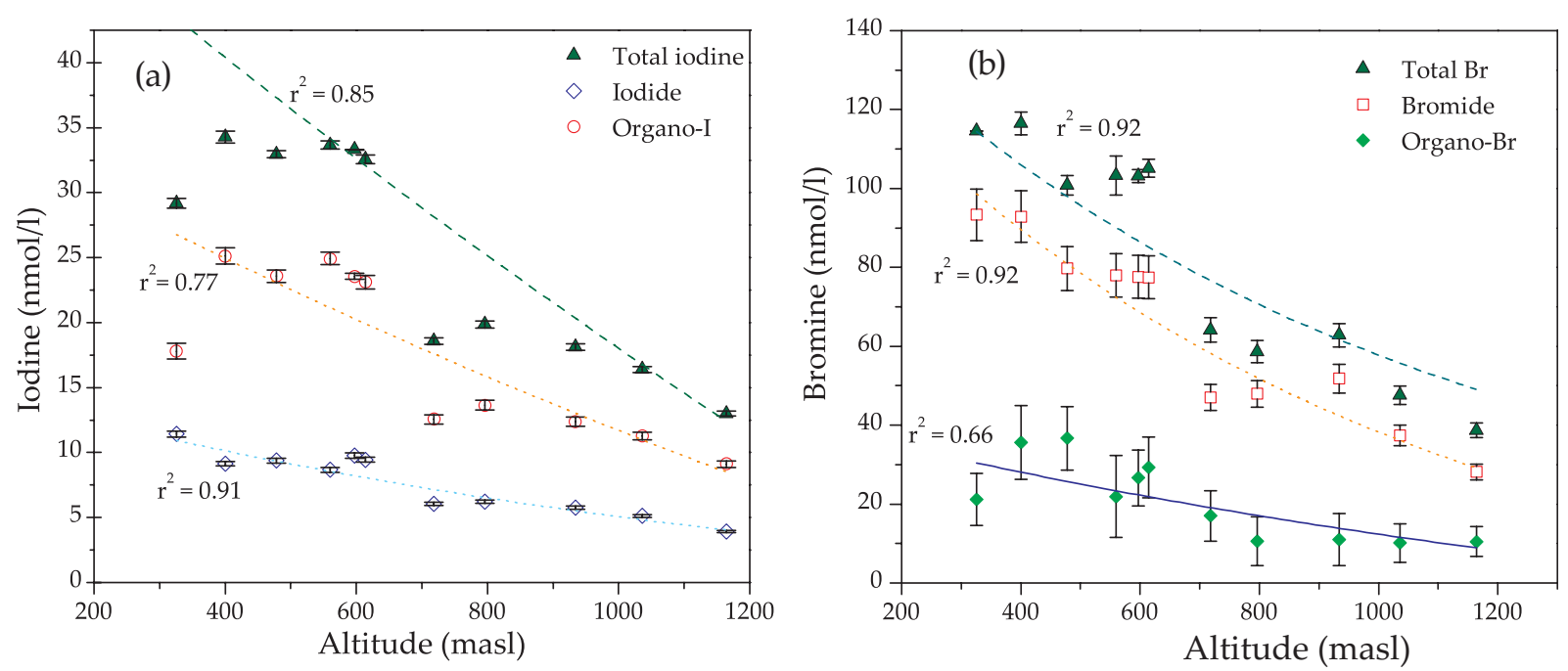

Fig. 2. (a) Total iodine, iodide, and organically bound iodine in snow vs. altitude. (b) Total bromine, bromide, and organically bound Br in snow vs. altitude. All data points are from the 11 and 12 February 2006 and fitted with exponential decay functions. Error bars represent analytical precision and were calculated as $1 \sigma$ of replicate analysis.

Molar iodine and bromine enrichment factors (EF) relative to seawater may be able to trace the origin of these elements (Winchester and Duce, 1967; Woodcock et al., 1971; Gilfedder et al., 2007). EFs are calculated by dividing the halogen to sodium ratios in snow by halogen to sodium ratios in seawater (e.g. I/Na in snow divided by I/Na seawater). When these enrichment factors are calculated, it is immediately apparent that iodine is highly enriched in snow (average EF 204, max. 281). EFs appear to increase linearly with elevation until $796 \mathrm{~m}$ a.s.l. $\left(r^{2}=0.95\right)$, whereafter the relationship is less clear (Fig. 5). If the sample from $934 \mathrm{~m}$ a.s.l. is excluded and a 2 nd order polynomial is fitted to the data it appears that the iodine EFs decrease after $\sim 800 \mathrm{~m}$ a.s.l. $\left(r^{2}=0.87\right)$. However, this is only based on the last two sample points and further studies are needed to confirm or refute this decrease in EF at higher altitudes. In contrast to iodine, bromine enrichment factors range from slightly depleted (0.7) at Ottenhöfen to no enrichment or only slightly enriched over the remainder of the transect (max. 1.4). Bromine enrichment factors also increases linearly with altitude $\left(r^{2}=0.84\right)$ up to $796 \mathrm{~m}$ a.s.l., whereafter the relationship again appears to decrease if the point from $934 \mathrm{~m}$ a.s.l. is removed ( $r^{2}=0.8$; Fig. 5). In part the anomalous trend in these last three points is due to Na following a decrease curve with a significantly different "decay" constant than iodine and bromine. We can also calculate iodine enrichment factors relative to bromine $(\mathrm{I} / \mathrm{Br}$ in snow divided by $\mathrm{I} / \mathrm{Br}$ in seawater). These EFs (av. 602, max. 665) show that iodine is more enriched relative to bromine than to sodium, however there is no relationship with altitude $\left(r^{2}=0.3\right.$; data not shown). Enrichment factors for iodine relative to bromine from the January samples were lower than those taken in February, averaging 402.

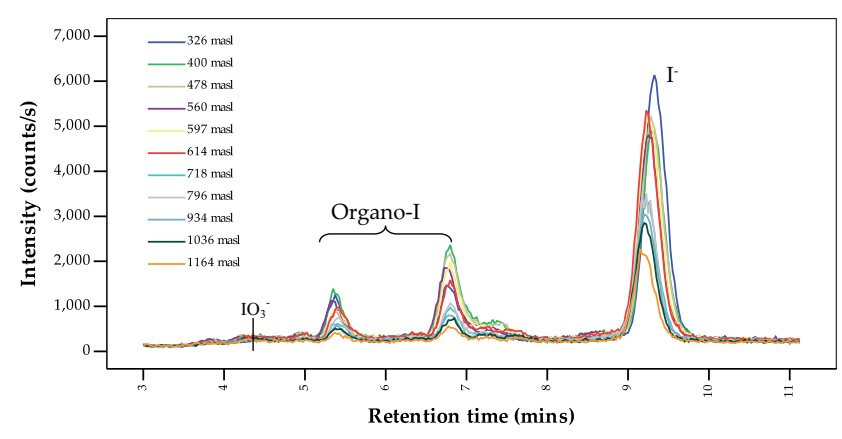

Fig. 3. IC-ICP-MS chromatogram of iodine species in snow. Iodate less than $0.3 \mathrm{nmol} / \mathrm{l}$. Largest iodide peak $11.4 \mathrm{nmol} / \mathrm{l}$.

\section{Discussion}

\subsection{Microphysical processes}

There is growing evidence that suggests iodine concentrations in rainfall are not simply related to distance from the ocean (Krupp and Aumann, 1999; Moran et al., 1999; Michel et al., 2002). While back trajectories are not given in any of these studies and the authors assume that the closest ocean is the source of rainfall, the data still appears to be relatively robust. The data presented here indicates that, compared to lateral distance, removal by orographically induced precipitation has a large effect on the total iodine concentrations as well as the individual iodine species in snow. In fact, iodine concentrations more than halve over a horizontal distance of only $5 \mathrm{~km}$ and a vertical change of $\sim 800 \mathrm{~m}$. Duce et al. (1965) found a relatively linear inverse relationship between height (and thus a decrease in vapor pressures 

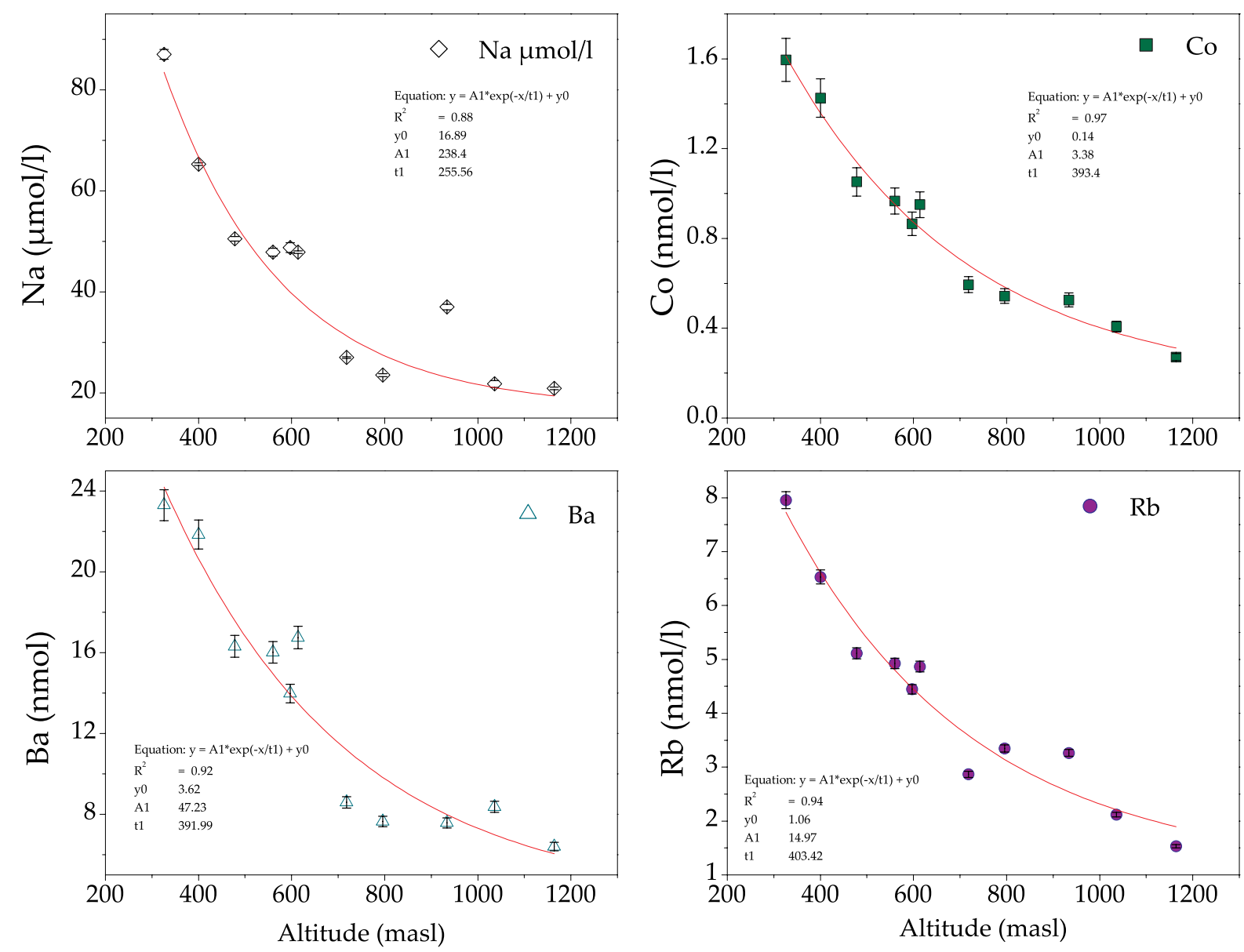

Fig. 4. Sodium, $\mathrm{Co}, \mathrm{Ba}$ and $\mathrm{Rb}$ concentrations in snow vs. altitude in the northern Black Forest, Germany. Fitted with exponential decay functions. Error bars represent analytical precision and were calculated as $1 \sigma$ of replicate analysis.

and assumingly an increase in the precipitation rate) and iodine concentrations in Hawaii, however the scatter in their data points was much greater than observed in this study. Interestingly, Reithmeier et al. (2006) have also suggested recently that, based on differences in ${ }^{129} \mathrm{I}$ concentrations between Zürich and the Fiescherhorn ( $4000 \mathrm{~m}$ a.s.l.) glacier Switzerland, radiogenic iodine is removed with increasing altitude. Moreover, the systematic exponential decrease in concentration is not confined solely to iodine and bromine as the 12 metals also analysed displayed a similar pattern. Our data suggest that depletion of elements due to orographic lifting and removal by precipitation is a general atmospheric microphysical processes rather than element specific. This is supported by the significant correlations between all of the elements, which also indicate that iodine, bromine and metals are internally mixed within the snow crystals. Such an altitude dependence for iodine is perhaps not unexpected considering that some of the areas most effected by iodine deficiency disorders are (or in some cases, were, before introduction of iodinated salt) located in mountainous regions such as the Alps or the Himalayas (Stewart, 1990; Slavin, 2005). Perhaps the altitude that a weather system must pass over, and thus the degree of orographically induced precipitation exerted on this system, will have the largest influence on iodine concentrations in snow rather than the lateral distance traveled.

All elements appear to follow an exponential decrease curve. It is especially difficult to model this complex system without significantly more data such as updraft velocity, droplet size distributions, riming potential, temperature at the time of precipitation, atmospheric pressure, and aerosol chemistry and distributions etc. It is even possible that two effects are occurring in unison to lower the iodine, bromine and metal levels with increasing altitude; the rainout and depletion effect suggested above, and also dilution due to condensation of water vapor (obviously iodine free) onto the snow crystals as the cloud parcel rises and cools. The rainout effect continually removes a portion of the "total" iodine available to precipitate, whereas the rate of the second, dilution effect, would increase with altitude due to the decreasing 
vapor pressure associated with lifting and cooling of the cloud mass. If we conceptually parameterize the rainout processes with arbitrary values (i.e. a set amount of iodine in the cloud is available to precipitate and the removal rate is constant with altitude) then iodine levels in the snow should decrease following an exponential decrease relationship similar to that observed here. This model is, however, undoubtedly too simplistic and should be further refined when more results are available. The second "dilution" possibility is more complicated to model, as modeling droplet (or snowflake) growth requires considerably more variables than measured here and is unfortunately out of the scope of this work. However, we suggest that future projects monitor such variables as vapor pressure, updraft speed, and supersaturation so that the possibility of a dilution effect due to growth from the vapor phase can be assessed.

\subsection{Speciation}

Iodine is of particular interest in atmospheric chemistry due to its possible role in new aerosol formation (O'Dowd et al., 2002), tropospheric ozone depletion (von Glasow and Crutzen, 2003; Calvert and Lindberg, 2004), atmosphereocean interactions (Duce and Hoffman, 1976) and more generally as an important constituent of tropospheric chemical cycles. While there has been a large research effort to quantify the gaseous iodine flux species from the ocean and their role in new particle formation in recent years, most of these studies have concentrated on inorganic speciation in the particulate and aqueous phase. Indeed, the majority of atmospheric models indicate that iodate should be the only stable long-term iodine species in particles and the aqueous phase, although more recent attempts have began to tackle this problem by incorporating an organic fraction (Vogt et al., 1999; McFiggans et al., 2000; Saiz-Lopez et al., 2006; Pechtl et al., 2007). However, it is becoming apparent that organically bound iodine is a major, if not the most important iodine species in sub-micron aerosol particles, rain, and snow (Baker et al., 2000; Baker, 2005; Gilfedder et al., 2007). It is obvious from the data presented here that organically bound iodine is the dominant species in snow from the northern Black Forest, accounting for between $60-75 \%$ of total iodine. To date, there appears to be three plausible mechanisms for the formation of organically bound iodine in the atmosphere; 1) ejaculation of iodo-organic rich material from the ocean surface micro-layer into the atmosphere during bubble bursting, whereafter the small droplets evaporate leaving a small aerosol which may subsequently deliquesce and become a cloud droplet (Seto and Duce, 1972; Cavalli et al., 2004); 2) biogenic iodine gases emitted from the ocean (e.g. $\mathrm{CH}_{3} \mathrm{I}, \mathrm{I}_{2}$ or $\mathrm{CH}_{2} \mathrm{I}_{2}$ ) are photolysed to $\mathrm{I}^{\circ}$ which, after a series of reactions, ends up as IO, $\mathrm{I}_{2}$ or HOI (von Glasow and Crutzen, 2003). These species may easily bind to atmospheric organic material, either gaseous (e.g. terpenes and/or isoprene (Greenberg et al., 2005)) or particulate matter; 3) Biogenic

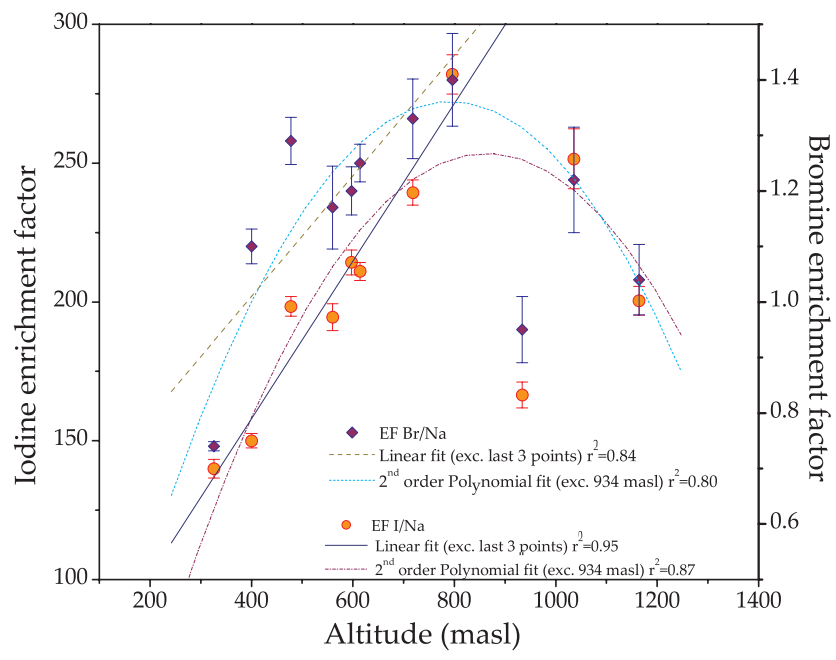

Fig. 5. Iodine bromine enrichment factors relative to seawater $\mathrm{Na}$ concentrations. Linear fit is excluding the last 3 samples whereas the polynomial is excluding the sample from $934 \mathrm{~m}$ a.s.l.

terrestrial organo-I emissions (Dimmer et al., 2000); these can probably be neglected in this study due to very little terrestrial biological productively during the European winter. The second mechanism may reduce the impact of iodine on ozone depletion in the troposphere by reactions between highly reactive iodine species and organic material. Mechanisms 1 and 2 could also be occurring simultaneously, which may lead to two organically bound fractions, those associated with secondary iodo-organics, and those associated with higher molecular weight material from the ocean surface. An interesting finding is the two unknown, most likely organic, peaks observed in the snow IC-ICP-MS chromatograms. These same species have also been observed in rain from Lake Constance, Germany, Patagonia, Chile and in a glacier core from the Fiescherhorn glacier (Gilfedder et al., 2007). This supports our earlier suggestion that these are important iodine species in the atmosphere, and may even be globally ubiquitous. Unfortunately, it has not been possible to identify these peaks with the standards available to date. These species may be formed by photolysis of iodoorganics derived from primary aerosols or by secondary gas phase-particle phase reactions.

The majority of the total bromine is bromide, of which the majority is most likely from ocean water as suggested by relatively little depletion or enrichment compared to this source. The organically bound bromine in snow (max. 32\%) may be derived from the ocean surface layer as discussed above for iodine or between reactive bromine species such as $\mathrm{BrCl}$ and organic material.

\subsection{Origin of the iodine and bromine}

Finally we consider the enrichment factors and the possible origin of iodine in snow. Iodine in snow is highly enriched 
relative to both iodine/bromine and iodine/sodium ratios in seawater. Similar enrichments are well documented in marine aerosols and rain samples and is thought to be a function of both fractionation at the ocean surface during bubble breaking and emissions of biogenic iodine gasses (Duce et al., 1965; Duce et al., 1967; Woodcock et al., 1971; Sturges and Barrie, 1988; Baker, 2004, 2005). The observation that the snow sampled here display almost identical enrichment factors as marine aerosols (Duce et al., 1965; Baker, 2005) tend to suggest that iodine and bromine in snow originate from deliquescence and growth of these aerosols. As such, we hypothesize that iodine is transported to the continents from the ocean primarily by aerosols and aerosol derived droplets. It is interesting to note that iodine enrichment factors in precipitation are also large in the winter, when biological productivity in the ocean is generally low at mid to high latitudes (O'Dowd et al., 2004). This suggests that at least a part of the enrichment is due to physical mechanisms such as bubble bursting rather than purely biological. As mentioned above, it is likely that the enrichment of iodine in aerosol, rain, and snow is related to both biological and physical mechanisms.

\section{Conclusions}

Iodine is an essential element for all mammals and may also be involved in new aerosol formation. We have presented here iodine and bromine speciation and total metal concentrations in snow over an altitude profile ranging from 326 to $1164 \mathrm{~m}$ a.s.l. in the northern Black Forest. Iodine species (total $\mathrm{I}^{-} \mathrm{I}^{-}$and organo-I), bromine species (total $\mathrm{Br}, \mathrm{Br}^{-}$, and organo- $\mathrm{Br}$ ) and metals decreased exponentially over the height change within only $5 \mathrm{~km}$ horizontal distance. In fact iodine concentrations more than halve over this distance. Therefore, it is suggested that orographic lifting of cloud masses and subsequent removal by precipitation is the major influencing factor on iodine and bromine concentrations in precipitation. This may reconcile previous data, which has been ambiguous as to the relationship between iodine concentrations in rainfall and distance from the coast. It is proposed that orographic cloud lifting and the intense precipitation this often produces by rapid cooling of the air mass may be the dominant influence on terrestrial iodine rather than horizontal distance.

Iodine:sodium ratios in snow from the northern Black Forest indicate that iodine is highly enriched compared to iodine:sodium ratios in ocean water, whereas bromine ranges from slightly depleted to slightly enriched relative to seawater. Based on these enrichment factors and their resemblance to marine aerosol it is proposed that iodine and bromine in snow are derived from deliquescence of marine aerosol and subsequent growth into snow crystals.

In contrast to most atmospheric models, which predict iodate as the only stable iodine species in particulate and aque- ous phases, organically bound iodine was the most abundant iodine species in snow, followed by iodide. No iodate was found in the snow samples from January or February although a small amount was observed in two samples of very old snow in April. The organic iodine probably originates from a combination of 1) ejaculation of iodine-rich material from the oceanic microlayer into the atmosphere as well as 2) addition of gaseous or (gas phased derived) reactive iodine species to preexisting organic molecules. Active species such as HOI, $\mathrm{I}_{2}$ and IO are likely candidates for such reactions. It is clear from this and previous studies that organic iodine is an important part of the atmospheric iodine cycle and as such warrants further attention.

Acknowledgements. This project was funded by the Deutsche Forschungsgemeinschaft BI 734/5-1/2 to H. Biester. B. S. G would also like to thank my colleagues and two anonymous reviewers who significantly improved earlier versions of this manuscript.

Edited by: W. T. Sturges

\section{References}

Baker, A. R.: Inorganic iodine speciation in tropical Atlantic aerosol, Geophys. Res. Lett., 31, L23502, doi:10.1029/2004GL020144, 2004.

Baker, A. R.: Marine aerosol iodine chemistry: the importance of soluble organic iodine, Environ. Chem., 2, 295-298, 2005.

Baker, A. R., Thompson, D., Campos, A. M., Parry, S. J., and Jickells, T. D.: Iodine concentrations and availability in atmospheric aerosol, Atmos. Environ., 34, 4331-4336, 2000.

Baker, A. R., Tunnicliffe, C., and Jickells, T. D.: Iodine speciation and deposition fluxes from the marine atmosphere, J. Geophys. Res., 106, 28 743-28 749, 2001.

Calvert, J. G. and Lindberg, S. E.: Potential influence of iodinecontaining compounds on the chemistry of the troposphere in the polar spring. I. Ozone depletion, Atmos. Environ., 38, 50875104, 2004.

Campos, M. L. A. M.: New approach to evaluating dissolved iodine speciation in natural waters using cathodic stripping voltammetry and a storage study for preserving iodine species, Mar. Chem., 57, 107-117, 1997.

Cavalli, F., Facchini, M. C., Decesari, S., Mircea, M., Emblic, L., Fuzzi, S., Ceburnis, D., Yoon, Y. J., O’Dowd, C. D., Putaud, J. P., and Dell'Acqua, A.: Advances in characterization of sizeresolved organic matter in marine aerosol over the north Atlantic, J. Geophys. Res., 109, 1-14, 2004.

Dimmer, C. H., Simmonds, P. G., Nickless, G., and Nickless, M. R.: Biogenic fluxes of halomethanes from Irish peatland ecosystems, Atmos. Environ, 35, 321-330, 2000.

Dobson, J. E.: The iodine factor in health and evolution, The Geographical Review, 88, 1-28, 1998.

Duce, R. A. and Hoffman, E. J.: Chemical fractionation at the air/sea interface, Annu. Rev. Earth Planet. Sci., 4, 187-228, 1976.

Duce, R. A., Winchester, J. W., and Van Nahl, T. W.: Iodine, bromine, and chlorine in the Hawaiian marine atmosphere, J. Geophys. Res., 70, 1775-1799, 1965. 
Duce, R. A., Woodcock, A. H., and Moyers, J. L.: Variation of ion ratios with size among particles in tropical oceanic air, Tellus, XIX, 369-379, 1967.

Fuge, R. and Johnson, C. C.: The geochemistry of iodine-a review, Environ. Geochem. Health, 8, 31-54, 1986.

Gilfedder, B. S., Petri, M., and Biester, H.: Iodine speciation in rain and snow: Implications for the atmospheric iodine sink, J. Geophys. Res., 112, D07301, doi:10.1029/2006JD007356, 2007.

Greenberg, J. P., Guenther, A. B., and Turnipseed, A.: Marine organic halide and isoprene emissions near Mace Head, Ireland, Environ. Chem., 2, 219-294, 2005.

Heumann, K. G., Gallus, S. M., Rädlinger, G., and Vogl, J.: Accurate determination of element species by on-line coupling of chromatographic systems with ICP-MS using isotope dilution technique, Spectrochim. Acta B, 53, 273-287, 1998.

Heumann, K. G., Rottmann, L., and Vogl, J.: Elemental speciation with liquid chromatography-inductively coupled plasma isotope dilution mass spectrometry, J. Anal. At. Spectrom., 9, 13511355, 1994.

Jickells, T. D., Davies, T. D., Tranter, M., Landsberger, S., Jarvis, K., and Abrahams, P.: Trace elements in snow samples from the Scottish Highlands: Sources and dissolved/particulate distributions, Atmos. Environ., 26A, 393-401, 1991.

Krupp, G. and Aumann, D. C.: The origin of iodine in soil: I. Iodine in rainfall over Germany, Chem. Erde, 59, 57-67, 1999.

McFiggans, G., Plane, J. M. C., Allan, B. J., and Carpenter, L. J.: A modeling study of iodine chemistry in the marine boundary layer, J. Geophys. Res., 105, 14371-14 385, 2000.

Michel, R., Ernst, T. H., Jackob, D., Klipsch, K., Szidat, S., Synal, H. A., and Schnabel, C.: Long-lived radionuclides in the environment: The case of iodine-129, EUROSAFE, http://www.eurosafe-forum.org/products/data/ 5/pe_235_24_1_euro2_4_2_iodine129.pdf?PHPSESSID= 933dfc3de630a555e394b81657d2af29, Berlin, 2002.

Moran, J. E., Oktay, S., and Santschi, P. H.: Sources of iodine and iodine 129 in rivers, Water Resour. Res., 38, 24-21 to 24-10, 2002.

Moran, J. E., Oktay, S., Santschi, P. H., and Schink, D. R.: Atmospheric dispersal of ${ }^{129}$ I from nuclear reprocessing facilities, Environ. Sci. Technol., 33, 2536-2542, 1999.

Moyers, J. L. and Duce, R. A.: Gaseous and particulate iodine in the marine atmosphere, J. Geophys. Res., 77, 5229-5238, 1972.

O'Dowd, C. D., Facchini, M. C., Cavalli, F., Ceburnis, D., Mircea, M., Decesari, S., Fuzzi, S., Yoon, Y. J., and Putaud, J.P.: Biogenically driven organic contribution to marine aerosol, Nature, 431, 676-680, 2004.

O’Dowd, C. D., Jimenez, J. L., Bahreini, R., Flagan, R. C., Seinfeld, J. H., Hameri, K., Pirjola, L., Kulmala, M., Jennings, S. G., and Hoffmann, T.: Marine aerosol formation from biogenic iodine emissions, Nature, 417, 632-636, 2002.
Pechtl, S., Schmitz, G., and von Glasow, R.: Modelling iodide iodate speciation in atmospheric aerosol: Contributions of inorganic and organic iodine chemistry, Atmos. Chem. Phys., 7, 1381-1393, 2007, http://www.atmos-chem-phys.net/7/1381/2007/.

Reithmeier, H., Lazarev, V., Rühm, W., Schwikowski, M., Gäggeler, H. W., and Nolte, E.: Estimate of European ${ }^{129} \mathrm{I}$ Releases Supported by ${ }^{129}$ I Analysis in an Alpine Ice Core, Environ. Sci. Technol., 40, 5891-5896, 2006.

Saiz-Lopez, A., Plane, J. M. C., McFigans, G., Williams, P. I., Ball, S. M., Bitter, M., Jones, R. L., Hongwei, C., and Hoffmann, T.: Modelling molecular iodine emissions in a costal marine environment: the link to new particle formation, Atmos. Chem. Phys., 6, 883-895, 2006,

http://www.atmos-chem-phys.net/6/883/2006/.

Sander, R., Keene, W.C., Pszenny, A. A., Arimoto, R., Ayers, G. P., Baboukas, E., Cainey, J. M., Crutzen, P. J., Duce, R. A., Hönninger, G., Huebert, B. J., Maenhaut, W., Mihalopoulos, N., Turekain, V. C., and Van Dingenen, R.: Inorganic bromine in the marine boundary layer: a critical review, Atmos. Chem. Phys., 3, 1301-1336, 2003, http://www.atmos-chem-phys.net/3/1301/2003/.

Schnell, D. and Aumann, D. C.: The origin of iodine in soil: Iodine in soils of Germany, Chem. Erde, 59, 69-76, 1999.

Seto, F. Y. B. and Duce, R. A.: A laboratory study of iodine enrichment on atmospheric sea-salt particles produced by bubbles, J. Geophys. Res., 77, 5339-5349, 1972.

Slavin, G.: Derbyshire neck and iodine deficiency, Mercian Geologist, 16, 79-88, 2005.

Stewart, A.: For debate: Drifting continents and endemic goiter in northern Pakistan, British Medical Journal, 300, 1507-1512, 1990.

Sturges, W. T. and Barrie, L. A.: Chlorine, bromine and iodine in arctic aerosols, Atmos. Environ., 22, 1179-1194, 1988.

Vogt, R., Sander, R., von Glasow, R., and Crutzen, P. J.: Iodine chemistry and its role in halogen activation and ozone loss in the marine boundary layer: A model study, J. Atmos. Chem., 32, 375-395, 1999.

von Glasow, R. and Crutzen, P. J.: Tropospheric halogen chemistry, in: Treatise on Geochemistry, edited by: Holland, H. D. and Turekian, K. K., Elsevier, 21-63, 2003.

Whitehead, D. C.: The distribution and transformation of iodine in the environment, Environ. Intern., 10, 321-339, 1984.

WHO: Iodine status worldwide, World Health Organization, Geneva, 1-46, 2004.

Winchester, J. W. and Duce, R. A.: The global distribution of iodine, bromine, and chlorine in marine aerosols, Naturewissenschaften, 54, 110-113, 1967.

Woodcock, A. H., Duce, R. A., and Moyers, J. L.: Salt particles and raindrops in Hawaii, J. Atmos. Sci., 28, 1252-1257, 1971. 